\title{
Motivational Factors in Multilingual Students' Learning Additional Languages: The Case of English and Turkish
}

\author{
Ali Dincer a *(i) \\ a Erzincan Binali Ylldırım University, English Language Teaching, Erzincan 24100, Turkey \\ Received 27 April 2018 | Received in revised form 24 July 2018 | Accepted 27 August 2018
}

\begin{abstract}
APA Citation:
Dincer, A. (2018). Motivational factors in multilingual students' learning additional languages: The case of English and Turkish. Eurasian Journal of Applied Linguistics, 4(2), 275-299. doi: 10.32601/ejal.464179
\end{abstract}

\begin{abstract}
The current study examined the relationships among motivational factors (i.e., motivation types and motivational strength, and language anxiety) in the simultaneous learning process of additional languages. A mixed-methods design was conducted with 86 multilingual learners learning both English and Turkish. The data were collected using a survey and follow-up open-ended questions about the motivational factors. There were three major findings of the study. First, the motivational factors in one language were positively correlated with the same factors in another. Second, although the learners' motivation (i.e., intrinsic, extrinsic and integrative) and motivational strength to continue their education showed no differences in both languages, their L2 anxiety towards learning additional languages was statistically different, in that learners were less anxious when learning English language than learning Turkish language. Third, multilingual learners' interest in learning other languages and willingness to integrate in the target language culture, the status quo of the target language in the global world and the level of unfamiliarity of the target language seem to play a role in the learners' beliefs of motivation, feeling in learning additional languages and intention to study languages. Overall, the study highlighted the role of multilingualism in learning English and Turkish. It also shed light on understanding L2 affective factors learning distinct L2s.
\end{abstract}

(C) 2018 EJAL \& the Authors. Published by Eurasian Journal of Applied Linguistics (EJAL). This is an open-access article distributed under the terms and conditions of the Creative Commons Attribution license (CC BY-NC-ND) (http://creativecommons.org/licenses/by-nc-nd/4.0/).

Keywords: Multilinguals; English; Turkish; motivation; anxiety; motivational strength.

\section{Introduction}

More than 6,000 languages are spoken throughout the world, and approximately 200 countries use two or more official languages (Skutnabb-Kangas, Maffi, \& Harmon, 2003). Therefore, it is not surprising for many people to be motivated to learn new languages and be a multilingual individual, which can be broadly defined as "someone who can communicate in more than one language" (Wei, 2008, p.4). Although there is a great deal of research on the superiority of multilingual learners

\footnotetext{
* Corresponding author. Tel.: +90-446-224-0089, ext. 42111

E-mail address: adincer@erzincan.edu.tr
} 
over monolingual native speakers in learning another language (e.g., Cenoz, 2013; Dewaele, 2007; Jessner, 2008; Lasagabaster, 2013; Thompson \& Khawaja, 2016), the question of which factors underpin the acquisition of other languages by multilingual learners still remains unresolved (Leung, 2016). In addition, there has been a burgeoning interest in investigating affective factors such as motivation and anxiety which can hinder or boost foreign/ second language (L2 $\dagger$ ) learning (Horwitz, 2001; Noels, 2001, 2009; Ushioda, 2009). However, research looking at the roles of motivational factors in multilingualism is scarce (De Angelis, 2007; Dörnyei \& AlHoorie, 2017; Duff, 2017; Henry, 2011; Thompson \& Lee, 2016). Furthermore, the current motivation literature is invaded by a higher number of empirical research devoted mostly to the study of English as an L2 (Boo, Dörnyei, \& Ryan, 2015). Interestingly, in spite of the recent 'multilingual turn' taking place in the field of L2 learning (Boo et al., 2015; May, 2014; Ortega, 2013), investigation of L2 motivation in learning languages other than English is a relatively uncharted terrain in the era of globalization and multiculturalism (Ushioda \& Dörnyei, 2017). Given that, this study attempted to unravel multilingual L2 learners' reasons for learning additional languages: English and Turkish. Taking a comparative perspective, the current study investigates L2 motivation, anxiety, and motivational strength to study these languages.

\subsection{Multilingualism and L2 learning}

It is commonly believed that "the more languages a person knows, the easier it becomes to acquire an additional language" (Cenoz, 2013, p.74). In other words, in comparison with monolingual learners, multilingual learners find it easier to learn a new language for several reasons.

Firstly, recent studies have found that multilingualism plays an effective and positive role in learning additional languages since multilingual learners have a broader linguistic repertoire and many mnemonic strategies to apply when necessary (Cenoz, 2013; Cummins, 2007; Kemp, 2007). In addition, multilingual learners can quickly transfer their existing knowledge to the further learning of additional languages, since they have more experience in language learning. Studies conducted in the multi-cultural contexts where the learners learn additional languages such as English speakers learning French in Canada (Swain, 2000), immigrants learning Spanish in Spain (Budría \& Swedberg, 2014) and Italian speakers learning Dutch in Belgium (Jaspaert \& Lemmens, 1990) have reported that learners who already had a knowledge of two or more languages had a certain level of superiority over monolingual students - these learners achieved relatively high scores and outperformed monolingual learners in acquiring third languages.

Secondly, as Dewaele and Wei (2013) have highlighted, knowledge of multiple languages is correlated with positive affective factors. This means that a learner with experience of learning several languages will be much more eager to learn

$\dagger$ In this study, L2 refers to both foreign and second language. 
additional languages and will have a high level of tolerance towards ambiguity (Dewaele \& Wei, 2013, 2014; van Compernolle, 2016). Supporting this finding, Thompson $(2013,2016)$ emphasized that the languages studied in the past play a positive role in the subsequent language learning and expand the multilinguals' ability to learn languages. Thompson developed the Perceived Positive Language Interaction (PPLI) framework for exploring the relationships between multilingualism and various individual differences (see Thompson, 2009, 2013 for further details). Consistent with the previous research, Thompson and Aslan (2015) found that there are significant differences between the multilingual language learners reporting positive language interactions between the learned languages and the learners classified 'No Positive Perceived Language Interaction, NPPLI.' In sum, the researchers found that PPLI learners had higher levels of confidence, stronger desires to learn English, and were in more contact with native speakers and cultures than the NPPLI learners. They also suggested that the PPLI with languages stimulates positive beliefs and attitudes towards learning additional languages.

Additionally, multilingualism has been linked to lower levels of anxiety, since prior exposure to several languages reduces levels of apprehension and fear towards using a foreign language for communication purposes (Dewaele, 2007; Dewaele, Petrides \& Furnham, 2008; Santos, Cenoz, \& Gorter, 2015; Thompson \& Khawaja, 2016; Thompson \& Lee, 2013). However, to obtain a better understanding of multilingualism and the language preferences of multilingual learners, further yet more systematic research is still needed in the field of language acquisition (Cenoz, 2013).

\subsection{L2 motivation}

Motivation, one of the affective factors in learning a second language, has been found to be one of the primary indicators determining success or failure in L2 learning. It has been viewed as a 'magic wand' for supporting long-lasting language learning, since it provides the initial drive for beginning and a later force sustaining L2 learning (Dörnyei 1998, 2001).

According to Dörnyei (1998), if students do not have sufficient motivation for learning and accomplishing goals, any curriculum or teaching practice will be useless, as motivation is a necessity and has great importance in the area of L2 learning. From a historical perspective, various models of motivation in language learning were put forward by researchers during the social psychological period, the cognitive-situated period, and the process-oriented period (Dörnyei, 2001). While the social context and interactions of an L2 learner were the main focus during the social psychological period, more emphasis was placed on the mental and internal processes of L2 learners during the cognitive-situated period. However, the acceptance of motivation as a dynamic factor led to the primary focus of the processoriented period being the motivational changes of L2 learners within the process of learning (Dörnyei, 2001). 
The most common L2 motivation models used today are the socio-educational model (Gardner, 1985), self-determination theory (SDT; Deci \& Ryan, 1985; Ryan \& Deci, 2017), and the L2 motivational self-system (L2MSS; Dörnyei, 2005, 2009). In his socio-educational model, Gardner (1985) explains L2 motivation as "the extent to which the individual works or strives to learn the language because of a desire to do so and the satisfaction experienced in this activity" (p. 10). With the Attitude/Motivation Test Battery (AMTB), Gardner assesses the motivation with three dimensions (i.e., Motivational Intensity, Desire to Learn the Language, and Attitudes towards Language Learning). In this model, there are also two variables that may take a role in L2 motivation, which are instrumental (i.e., learning for functional reasons and attaining benefits such as money) and integrative motivation (i.e., learning for communicating and integrating with the target language community). An adaptation of SDT in L2 motivation (Noels, 2001; Noels, Clément, Pelletier, \& Vallerand, 2000) highlights the motivational continuum from the least self-determined to the most self-determined orientations. That is, it highlights amotivation (i.e., lack of motivation), extrinsic (i.e., learning a language for external reward or avoiding punishment) and intrinsic (i.e., learning a language for personal joy or satisfaction) motivation. The L2MSS conceptualizes the ideal L2 self (the L2specific facet which the learner ideally would like to possess), the ought-to L2 self (the attributes that the learner think that s/he ought to be possessed to avoid a negative outcome) and the L2 learning experience ("situation-specific motives related to the immediate learning environment and experience") (Dörnyei, 2005, p.106). In addition to these perspectives, a broad-spectrum model is also used. This model synthesizes various theories of motivation and combines a number of elements such as intrinsic versus extrinsic motivation, integrative versus instrumental motivation, anxiety, and interest (Schmidt, Boraie, \& Kassabgy, 1996). Although a range of models and perspectives exist for investigating L2 and they share some commonalities, they are not identical and have distinct characteristics in describing L2 motivation.

\subsection{Multilingualism and motivational factors}

Although there is a large body of L2 research examining the relationships between language learning and motivation, the interface between L2 motivation and multilingualism has been under-investigated (e.g., Henry 2010, 2011; Thompson \& Erdil-Moody, 2016; Thompson \& Lee, 2016).

For instance, Csizér and Lukács (2010) carried out a comparative analysis of the attitudinal and motivational dispositions of students learning English and German as second and third additional languages, using the 'self' framework of Dörnyei (2001), also known as the L2 motivational self-system (L2MSS). In their study, the authors illustrated the complexity of the L2 motivation process involved in learning two languages simultaneously. The results indicated that students' motivational and attitudinal dispositions varied considerably according to their choices of English and German as second and third languages. To illustrate, the students who chose 
English as an L2 were the most motivated students and displayed the most positive attitudes and the least L2 anxiety about the L2 learning process.

In another study, Henry (2010) investigated the impact of English on foreign language (Spanish, French, and German) motivation during simultaneous language learning in the Swedish context. Henry hypothesized the potential negative effects of English in learning additional languages based on the previous quantitative findings (Csizér \& Lukács, 2010). Consistent with the hypothesis, Henry found that English had a negative impact on L2 motivation to study other languages.

In a more recent study, Thompson and Erdil-Moody (2016) investigated the differences between the perceptions of bilingual and multilingual learners' ideal and ought-to L2 selves, and a perceived positive interaction within the framework of Dörnyei (2001). They found that multilingual learners had a significantly higher ideal L2 self than did the bilinguals. Similarly, the learners who perceived positive interaction with the studied language had a significantly higher ideal L2 self than did those learners with no perceived positive interaction.

Recently, Thompson and Lee (2016) explored motivational factors within a group of Korean university language learners who were identified on a scale of English proficiency and degree of multilingualism. Using the Motivational Factors Questionnaire (MFQ, Ryan 2009) as the primary instrument in their study, the researchers first carried out a factor analysis to see the underlying constructs and then performed a MANOVA to validate the survey. Similar to Ryan's study, they proposed new dimensions for Dörnyei's ideal L2 self. They identified motivationrelated factors, such as learners' levels of anxiety, cultural interest, and attitudes towards the target language, community-predicted language proficiency, and multilingual status. In addition to these factors, Henry (2017) proposed a recent multilingual motivational self-system in order to describe the complementary relations in multilingual language learning process and conceptualized the ideal multilingual self which is about the emergent property of interactions between the languages known or being learned.

The research described above focuses on the issue solely from the perspective of Dörnyei's L2MSS in order to examine the associations between L2 selves, bilingualism, and multilingualism. The existing body of literature on this subject has therefore been shaped primarily by a handful of studies addressing the self (Csizér \& Lukács, 2010), toleration towards other languages (Dewaele \& Wei, 2013), anxiety in learning an additional language (Thompson \& Lee, 2013) and affective factors such as motivational strength and parental encouragement (Lasagabaster \& Dois, 2015). Although Thompson and Lee (2016) adopted a much broader perspective influenced by the L2MSS and contributed a more detailed level of knowledge about the predictability of multilingual vs. bilingual status over a range of individual differences, the current literature still lacks other elements related to L2 motivation such as L2 anxiety and motivational strength to study languages. An analysis of the broader perspective of the motivational disposition of L2 learners is still needed. L2 
motivation has a multi-faceted nature (Schmidt et al., 1996), and different models and frameworks are comprising affective, pragmatic, macro-context-, self-, educational context-, significant others- related dimensions in the motivation research (Dörnyei,1990, 1998, 2001).

Although L2 motivation literature is extensively invaded with the studies learning of English as L2 (e.g., Boo et al., 2015) and is slowly being expanded with research investigating motivational factors in less commonly taught languages like Turkish (e.g., Varisoglu, 2018), there is a scarcity of research on learning languages other than English in the era of globalization and multiculturalism (Ushioda \& Dörnyei, 2017). In addition, limited research has been conducted to investigate simultaneous L2 learning situations, and also to compare and contrast L2 motivation in the languages being learned by multilingual learners (Csizér \& Lukács, 2010; Henry, 2010; Thompson \& Erdil-Moody, 2016; Thompson \& Lee, 2016).

\subsection{The study}

The current study pieced different factors together to investigate the relationships between the factors related to L2 motivation during the simultaneous learning of foreign languages in a single study. Then, a broad-spectrum model was adapted (see Schmidt \& Watanabe, 2001). This model synthesizes various theories of motivation (e.g., the socio-educational model, see Gardner, 1985 and self-determination theory, see Noels, 2001), shares some commonalities, and combines a number of elements such L2 anxiety and motivational strength in describing L2 motivation. Therefore, the study banded intrinsic versus extrinsic motivation, integrative motivation, L2 anxiety, and motivational strength of the learners. English, an internationally recognized language, and Turkish, a less commonly known language, were selected to explore learners' perceptions regarding both languages.

In terms of the study context, Turkey has comparatively low rates of success in teaching English as a Foreign Language (EFL) (BC \& TEPAV, 2013) and many cultural and linguistic issues arise in teaching English (Thompson \& Erdil-Moody, 2016). However, teaching Turkish as a Foreign Language (TFL) is mainly ruled by language teaching centers accredited by Turkish Language Teaching, Research and Application Center (Turkish acronym, TOMER) in Turkey. By taking all these directions, the following research questions guided this study:

1. What are the correlations between motivational factors (i.e., motivation types, L2 anxiety, and motivational strength) of multilingual learners in learning English and Turkish as additional languages?

2. Do motivational factors of multilingual learners regarding English and Turkish differ from each other?

3. What are multilingual learners' beliefs about learning English and Turkish in terms of motivational factors? 


\section{Method}

\subsection{Research design}

In this mixed-methods research, a concurrent triangulation design was adopted, and the design was shown in Figure 1.

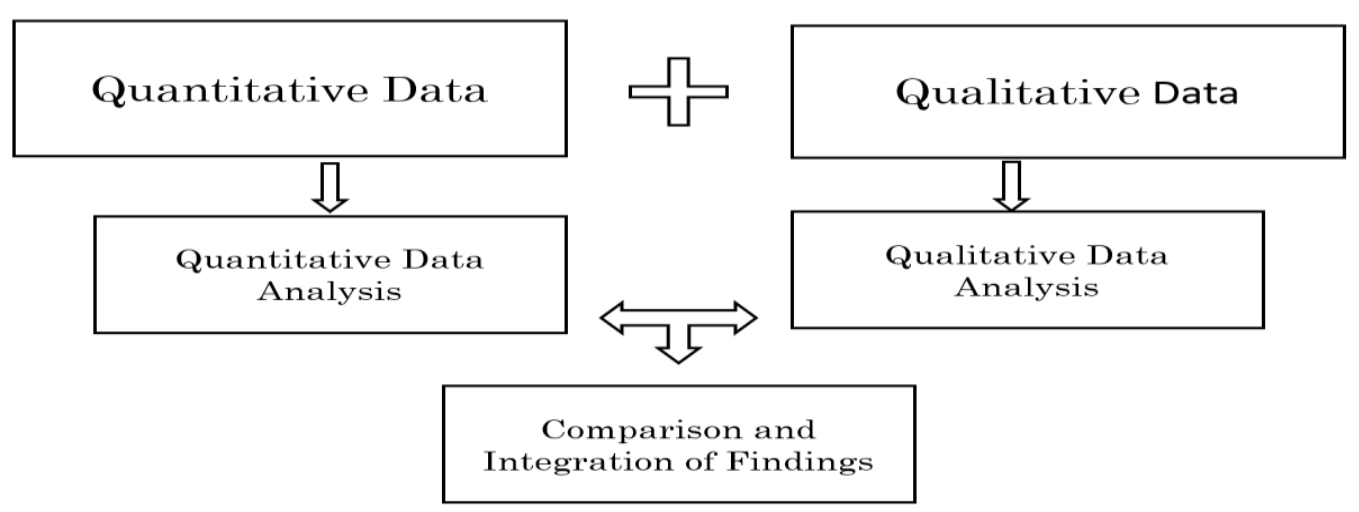

Figure 1. Research design

According to Creswell and Clark (2007), both quantitative and qualitative data were concurrently collected to provide thorough responses to the research questions. The researcher uses this design in an attempt to cross-validate or corroborate findings (Hanson, Creswell, Plano Clark, Petska, \& Creswell, 2005). In the present study, both data were concurrently collected and analyzed at the same time. The findings from the data were merged to see the relationships and reasons of the relationships in multilingual learners' motivation, L2 anxiety and motivational strength across languages at the interpretation stage.

\subsection{The study context}

The study context is a Turkish Language Teaching, Research and Application Center of a state university located in Turkey. The learning center aims to teach several languages apart from Turkish to international students who come to Turkey for a number of reasons such as pursuing educational degrees, getting a job, having Turkish citizenship, and so forth.

\subsection{Participants}

Eighty-six international students (27 males and 59 females) enrolled in the TOMER located in Turkey participated. The convenience sampling method was used in this study. In addition, 30 of the participants also responded to the open-ended interview questions by writing their viewpoints regarding learning both languages. The total participants were coming from 39 different nationalities (see Table 1). Their ages were in the range of 17 to 33 years $(M=22.76 ; S D=3.77)$. 
Table 1. Distribution of international students based on their nationalities

\begin{tabular}{|c|c|c|c|c|c|}
\hline Nationality & $\mathrm{n}$ & Nationality & $\mathrm{n}$ & Nationality & $\mathrm{n}$ \\
\hline Afghan & 9 & Egyptian & 1 & Moroccan & 1 \\
\hline Albanian & 1 & Filipino & 2 & Pakistani & 3 \\
\hline Arab & 4 & Gabonese & 1 & Serbian & 1 \\
\hline Azerbaijani & 3 & Indian & 1 & South Korean & 1 \\
\hline Bangladeshi & 1 & Iranian & 1 & Somalian & 3 \\
\hline Bosnian & 4 & Iraqi & 9 & Sudanese & 1 \\
\hline Bulgarian & 1 & Kazakh & 5 & Syrian & 2 \\
\hline Burkinian & 1 & Kosovan & 1 & Taiwanese & 2 \\
\hline Central African & 1 & Kyrgyzstani & 2 & Tajikistani & 2 \\
\hline Chadian & 1 & Macedonian & 1 & Tatar & 1 \\
\hline Chinese & 4 & Mauritanian & 1 & Togolese & 1 \\
\hline Colombian & 3 & Mexican & 1 & Uzbek & 2 \\
\hline Djiboutian & 2 & Montenegrin & 1 & Yemeni & 4 \\
\hline
\end{tabular}

Note. Numbers represent the frequencies.

According to the self-reported demographic information, all participants can speak at least two languages. Some participants reported they could speak a third language other than English and Turkish. All participants were also in the process of learning English and Turkish languages.

Table 2. Perceived language proficiencies

\begin{tabular}{lcccccc}
\hline Languages & Beginner & $\%$ & Elementary & $\%$ & Intermediate & $\%$ \\
\hline English & 12 & 14 & 28 & 32.05 & 46 & 53.5 \\
Turkish & 11 & 12.8 & 43 & 50 & 32 & 37.2
\end{tabular}

As can be seen in Table 2, the self-rated proficiency levels of the participants in English and Turkish varied from beginner to intermediate. However, most participants reported that their level of English is intermediate and their level of Turkish is elementary on a scale from 1 (Beginner) to 3 (Intermediate).

Table 3. Mostly stated L1 and L2 of the participants

\begin{tabular}{lll}
\hline Languages & L1 & L2 \\
\hline Arabic & 25 & 14 \\
French & 6 & 11 \\
Kurdish & 0 & 9 \\
Persian & 7 & 4 \\
Russian & 3 & 11 \\
\hline
\end{tabular}

Note. Numbers represent the frequencies. 
Table 3 presents the frequency of the first and second languages spoken by the participants. Twenty-nine different languages were reported by the learners, but only the languages with high-frequency rate (L1 or L2= seven or more) were listed in the table. As shown in Table 3, Arabic was the most common L1 and L2 as well, followed by French and Russian.

\subsection{Instruments}

The qualitative data were gathered using a questionnaire about the motivational constructs repeated for each additional language. This tool was originally developed by Schmidt et al. (1996) to explore motivational factors in learning EFL. It was later adapted for other contexts and used in the studies of Schmidt and Watanabe (2001) and Balaman-Uçar (2009) to explore the interaction between the activity preferences and motivational styles of foreign language learners. Schmidt and Watanabe (2001) tested the reliability of the subscales in four different contexts (Japanese, European, Filipino and Chinese) and found acceptable Cronbach's alpha levels in European group as follows: intrinsic $=.86$; extrinsic $=.64$; integrative $=.73$; anxiety $=.73$ and motivational strength $=.74$. For the present study, five subscales totaling 26 items adapted from the questionnaire (Schmidt \& Watanabe, 2001) were employed in light of the framework of the study. Adapted scales were both in English and Turkish. English version was used for learning English, and Turkish version was used for learning Turkish. All the items were five-point Likert scales: (1) strongly disagree, (2) disagree, (3) neither disagree nor agree, (4) agree, (5) strongly agree. In the following part, further details about the scales are shared (see also Appendix for the whole questionnaire).

a) Intrinsic motivation: It is the most self-determined motivational orientation and concerns learning a language for personal happiness and enjoyment. The scale has five items, and Cronbach alphas' for English is .75 and for Turkish is .74. A sample item is "I am studying this language because learning this language is very enjoyable."

b) Extrinsic motivation: It is the least self-determined motivation orientation and relates to learning a language to gain practical benefits such as reward, money or reputation. The scale has four items with acceptable reliability coefficients (Cronbach's alphas = .79 for English; .81 for Turkish). A sample item is "I am studying this language to get a better job.”

c) Integrative motivation: It refers to learners' reason for learning a language to integrate themselves into the target language community and to be part of the L2 user community. The scale has four items, and the Cronbach's alpha for each language is as follow: .68 for English; .66 for Turkish. The sample item is "I am studying this language because I want to be closer to the culture of this language."

d) L2 anxiety: Anxiety in the L2 domain is about the negative feelings of the learners and their fear during the language learning process. The scale has seven items with acceptable reliability coefficients (Cronbach's alphas $=.76$ for English; 
.82 for Turkish). A sample item of the scale is "When I take an exam in this language, I feel uneasy."

e) Motivational strength to study languages: It is mainly about L2 learners' intention to continue studying a language. The scale has six items with acceptable reliability coefficients (Cronbach's alphas $=.82$ for English and Turkish, as well). The sample item of the scale is "I will continue to study this language after I finish this class."

The qualitative data were collected through three open-ended questions in an interview format for each target language to gain a deeper understanding. The questions are as follows: Why do you study English / Turkish? How do you feel while learning English / Turkish course? Do you want to continue studying English / Turkish after your graduation?

\subsection{Data collection and analyses}

The data were collected in spring 2016. After securing the institutional approval of data collection, the learners were asked to participate in a paper-based survey study. The instruments including demographic information (i.e., gender, age, nationality, perceived proficiency in each language, and languages that they speak) were given to the learners during their language courses and the learners were informed about anonymity and voluntary participation by the researcher. All participants answered the questions in a written format and were free to express their thoughts in either English or Turkish. Data collection took about 25 minutes for each class. A total of 105 survey papers were collected. Nineteen participants who stated that their L1 and/or L2 was/were English or Turkish were excluded from the analyses. Quantitative data analyses were carried out with SPSS 21.0. A Pearson Product-Moment Correlation Coefficient and Paired Sample T-tests were computed to examine the relationships among variables and to identify differences across languages.

In the qualitative data analysis phase, the deductive content analysis approach was adopted. This analysis allowed to retest existing data by creating a categorization matrix and coding according to the matrix (Marshall \& Rossman, 2016). The responses given to the open-ended questions in the survey paper were systematically analyzed for the repeated statements and put into more specific categories to reach more abstract and general outcomes by the researcher. Extracts from the students' responses to the interview questions were also presented with the findings.

\section{Results}

\subsection{The relationships between motivational factors in learning English and Turkish}

Firstly, basic descriptive statistics were computed for each variable, and it was found that the learners largely agreed with the items related to motivational types 
and strength to study the languages in general, with minimum mean scores above $3.41(S D=.68 ; 3=$ Moderately Agree). However, learners had relatively low levels of anxiety in both languages, with the highest mean score being $2.60(S D=.88 ; 2=$ Disagree).

Table 4. Correlations between variables across languages

\begin{tabular}{|c|c|c|c|c|c|}
\hline English & $\begin{array}{l}\text { Intrinsic } \\
\text { Motivation }\end{array}$ & $\begin{array}{l}\text { Extrinsic } \\
\text { Motivation }\end{array}$ & $\begin{array}{l}\text { Integrative } \\
\text { Motivation }\end{array}$ & L2 Anxiety & $\begin{array}{l}\text { Motivational } \\
\text { Strength }\end{array}$ \\
\hline 1-Intrinsic Motivation & $.54^{* *}$ & & & & \\
\hline 2-Extrinsic Motivation & $.37^{* *}$ & $.43^{* *}$ & & & \\
\hline 3-Integrative Motivation & $.46^{* *}$ & $.33^{* *}$ & $.44^{* *}$ & & \\
\hline 4-L2 Anxiety & $-.23^{*}$ & $-.27^{*}$ & $-.29 * *$ & $.42^{* *}$ & \\
\hline 5- Motivational Strength & $.46^{* *}$ & $.24^{*}$ & $.35^{* *}$ & $-.27^{*}$ & $.64^{* *}$ \\
\hline
\end{tabular}

The correlation analysis showed that there was a significant correlation between variables in different magnitudes (see table 4). Overall, there was moderate positive correlation between intrinsic motivation in English and Turkish $\left(r=.54, \mathrm{r}^{2}=.29, \mathrm{p}<\right.$ $.01)$, extrinsic motivation in English and Turkish $\left(\mathrm{r}=.43, \mathrm{r}^{2}=.18, \mathrm{p}<.01\right)$, and integrative motivation in English and Turkish $\left(\mathrm{r}=.44, \mathrm{r}^{2}=.18, \mathrm{p}<.01\right)$. In addition, there was a positive correlation between L2 anxiety in English and Turkish $(r=.42$, $\left.\mathrm{r}^{2}=.17, \mathrm{p}<.01\right)$ and motivational strength in English and Turkish $\left(\mathrm{r}=.64, \mathrm{r}^{2}=.41, \mathrm{p}<\right.$ .01). Also, L2 anxiety was negatively correlated with motivational subtypes and motivational strength as negatively worded. According to the discipline-specific benchmarks of effect sizes ( $r=.25$ Small; $r=.40$ Medium; $r=.60$ High) of Plonsky and Oswald (2014), though the correlations were statistically significant, the variables, intrinsic, extrinsic and L2 anxiety in one language only accounted small amount of the variance in another language (e.g., L2 anxiety in English accounted only 17\% of the anxiety in Turkish or vice versa). There is a moderate effect size between the intrinsic motivations in both languages (26\%). Motivational strength with its highest effect size in one language can predict $41 \%$ of the strength in another language.

\subsection{Differences or similarities between motivational factors in learning English and Turkish}

Following the correlation analysis, paired sample t-tests were performed for L2 motivation types, L2 anxiety and motivational strength in the languages separately. As multiple t-tests were conducted at the same time, it was highly likely that the Type I error rate also increased. Given that, to minimize the error, Bonferroni corrections were applied by dividing the alpha level ( $\left.\alpha_{\text {original }}=.05\right)$ by the number of comparisons (i.e., a altered $=.05 / 5)$. Therefore, the new alpha level for the test in the 
present study was accepted as $\alpha=.01$. To consider the t-test to be statistically significant, the $\mathrm{p}$-value must be $\mathrm{p} \leq .01$. The test findings were presented in Table 5 .

Table 5. Comparison of motivational factors in English and Turkish

\begin{tabular}{|c|c|c|c|c|c|c|}
\hline Variables & Groups & M & $\mathrm{SD}$ & $\mathrm{t}$ & $\mathrm{df}$ & $\mathrm{p}$ \\
\hline \multirow[t]{3}{*}{ 1-Intrinsic Motivation } & English & 3.58 & .68 & \multirow{3}{*}{-2.373} & \multirow{3}{*}{86} & \multirow{3}{*}{.020} \\
\hline & & & & & & \\
\hline & Turkish & 3.41 & .68 & & & \\
\hline \multirow[t]{2}{*}{ 2- Extrinsic Motivation } & English & 4.07 & .82 & \multirow[b]{2}{*}{-2.102} & \multirow[b]{2}{*}{86} & \multirow[b]{2}{*}{.039} \\
\hline & Turkish & 3.86 & .91 & & & \\
\hline \multirow[t]{2}{*}{ 3-Integrative Motivation } & English & 3.43 & .90 & \multirow[b]{2}{*}{1.004} & \multirow[b]{2}{*}{86} & \multirow[b]{2}{*}{.318} \\
\hline & Turkish & 3.53 & .87 & & & \\
\hline \multirow[t]{2}{*}{ 4- L2 Anxiety } & English & 2.29 & .88 & \multirow[b]{2}{*}{3.184} & \multirow[b]{2}{*}{86} & \multirow[b]{2}{*}{$.002 *$} \\
\hline & Turkish & 2.61 & .84 & & & \\
\hline \multirow[t]{2}{*}{ 5- Motivational Strength } & English & 3.75 & .84 & \multirow[b]{2}{*}{.978} & \multirow[b]{2}{*}{86} & \multirow[b]{2}{*}{.331} \\
\hline & Turkish & 3.83 & .86 & & & \\
\hline
\end{tabular}

Note. ${ }^{*} \mathrm{p}<.01$ level.

The findings suggest that the variables, intrinsic motivation, extrinsic motivation, integrative motivation and motivational strength did not differ significantly at $\mathrm{p}<$ .01 level. The only L2 anxiety differed significantly and the students reported lower anxiety levels for English $(M=2.29, S D=.88)$ than Turkish $(M=2.61, S D=.84$; $t(85)=3.184, \mathrm{p}=.002, \mathrm{~d}=.37)$. These results suggest that the multilingual learners have similar characteristics regarding learning different languages in terms of the motivational variables. Though their means in motivational types and motivational strength regarding learning English were higher than the means in Turkish, these differences were not statistically significant. However, the students experienced higher L2 anxiety in learning Turkish than English.

\subsection{Beliefs about learning English and Turkish in terms of motivational factors}

Thirty students responded to the follow-up interview questions, and their responses were categorized under several themes. As can be seen in Table 6, certain parts were extracted from participant responses to highlight the major factors of their ideas about each language.

\subsubsection{Motivation for learning additional languages}

In the first question, the students listed a number of reasons for learning each language. Their answers were categorized into three motivation types, and two other themes (i.e., the universality of English and travel orientation) emerged for English. 
Table 6. Emerging themes and categories of L2 motivation

\begin{tabular}{|c|c|c|}
\hline Language & Themes & Categories \\
\hline \multirow[t]{4}{*}{ English } & Intrinsic motivation & $\begin{array}{l}\text { Inherent interest in languages and cultures } \\
\text { Love English } \\
\text { For enjoy of learning }\end{array}$ \\
\hline & Extrinsic motivation & $\begin{array}{l}\text { Reach educational goals } \\
\text { Gain superiority in job-market } \\
\text { Personal development } \\
\text { Easiness of learning English }\end{array}$ \\
\hline & Integrative motivation & $\begin{array}{l}\text { To live in an English-speaking country } \\
\text { Learn much about American culture } \\
\text { Make English-speaking friends }\end{array}$ \\
\hline & $\begin{array}{l}\text { Universality of English } \\
\text { Travel }\end{array}$ & $\begin{array}{l}\text { English as an international language } \\
\text { Travel across the world }\end{array}$ \\
\hline \multirow[t]{3}{*}{ Turkish } & Intrinsic motivation & $\begin{array}{l}\text { Inherent interest in languages and cultures } \\
\text { Personal happiness } \\
\text { Enjoy of speaking Turkish }\end{array}$ \\
\hline & Extrinsic motivation & $\begin{array}{l}\text { Reach educational goals } \\
\text { Get a job } \\
\text { Necessity to use in daily life } \\
\text { Personal development } \\
\text { Gain monetary reward } \\
\text { Family pressure }\end{array}$ \\
\hline & Integrative motivation & $\begin{array}{l}\text { Live in Turkey } \\
\text { Love Turkey and Turkish culture } \\
\text { Communicate with friends and Turks } \\
\text { Learn much about Turkish culture }\end{array}$ \\
\hline
\end{tabular}

According to Table 6, five themes related to learning English emerged from the analysis. Inherent interest to learn languages and cultures, love and joy of learning English are the among statements linked to intrinsic motivation. On this issue, one student, for instance, said: "[I am learning English], to be familiar with other cultures."

The students listed various extrinsic reasons for learning English. The reasons are mostly about reaching educational goals (e.g., educational goals; doing academic research or earning a university degree) and gaining some privileges in job-market (e.g., better job opportunities). Supporting this issue, one student said: "[I am learning English, because] I am doing my master, and I need English for scanning the literature." Unlike the other motivation types, the students listed some integrative reasons by expressing their goal of living in L2 language community in 
the future. Regarding this issue, one student said: "[I am learning English], because I would like to live in an English-speaking environment." In addition to these three themes, many learners stated that they would like to learn English for the international use of the language and for traveling comfortably across the world. As these reasons do not have probes clarifying the orientation (sample answers: "Because it is an international language," "I would like to travel around the world"), they were accepted as distinct categories. Regarding the role of English in today's world, one student said: "[I am learning English], because it is an international language that everybody must learn." And another student said: "Knowing English makes easy your job all over the world."

When it comes to learning Turkish, three themes emerged, and categories in learning Turkish showed similarities between learning English. Inherent interest in other languages and cultures is a highly reported reason for multilingual learners. Supporting this finding, a student said: "[I am learning Turkish in order] to be familiar with other cultures for both English and Turkish." They also listed other intrinsic reasons such as "[I am learning Turkish], because I love Turkish" or "Learning Turkish is enjoyable." The students also gave several extrinsic reasons for learning Turkish. Reaching educational goals such as completing a school requirement, doing academic research or earning a university degree are the most cited reasons. Another student said, "I did not want to learn Turkish, but I am obliged to learn it because of my educational career." This is a requirement for some students. Also, they also think that learning Turkish will help them work in international companies or Turkish companies. Besides, as the learners were living in Turkey, they might have felt an external pressure and expressed the necessity of learning Turkish. Supporting this finding, a student said: "[I am learning Turkish], because now I am living in Turkey." Few students also gave many extrinsic reasons such as family pressure or monetary reward such as scholarship. In terms of integrative reasons for learning Turkish, aiming to live in a target language community in the future seemed the most important reason for the learners, and the reasons such as loving the cultural elements of Turkey, communicating with the Turkish-speaking community were more important reasons for the students. A student giving integrative reasons for learning Turkish said: "[I am learning Turkish], to know well the culture of Turkish people [and] communicate well to Turkish people."

\subsubsection{Feeling while learning additional languages}

The second open-ended question asked students how they felt in their Turkish and English classes. Emerging themes and categories for each language from their answers are shown in Table 7. 
Table 7. Emerging themes and categories of feelings

\begin{tabular}{lll}
\hline Language & Themes & Categories \\
\hline English & Relaxed & Supportive course atmosphere \\
& & Familiarity with English \\
& Joy of learning English \\
& Anxious & \\
& & Limited L2 proficiency \\
& Boredom & Irrelevant teaching method \\
Turkish & Relaxed & Irrelevant teaching method \\
& & Supportive course atmosphere \\
& & Joy of learning Turkish \\
& & Interest in other languages \\
& Anxious & Linguistic familiarity \\
& Boredom & Unsupportive course atmosphere \\
& & Irrelevant teaching method \\
\hline
\end{tabular}

According to Table 7, three themes were extracted from the responses for each language. The students highlighted supportive course atmosphere such as voluntary participation policy and experienced teachers, being exposed to English for a long time, the joy of learning the languages and the particular linguistic features of Turkish made them relaxed while learning the languages. The relative newness of the language and the irrelevance of language teaching methods are the factors causing them to have anxiety while studying languages. Supporting this finding, a learner said "I am very relaxed [while studying English] because I was exposed much English before." and "I am anxious [while studying Turkish] because learning a new language is stressful." The students also said that the irrelevance of teaching methods make them bored in the class. On this issue, one learner said: "I am anxious [while studying Turkish] because Turkish is not an easy language to learn and also the methods used to make students understand are not good. So, it makes the language learning boring."

\subsubsection{Motivational strength for learning additional languages}

In the third question, the students were asked whether they would like to continue studying the languages after the course was over. Most of the respondents reported that they would like to go on learning the languages after completing the course. The emerging themes and categories from their answers are shown in Table 8. 
Table 8. Emerging themes and categories of motivation strength

\begin{tabular}{lll}
\hline Language & Themes & Categories \\
\hline English & I will continue & International role of English \\
& & Reach education purposes \\
& Interest in languages \\
& Love learning English \\
& & Job opportunities \\
& I will not continue & \\
& It depends & Long years of studying \\
I will continue & Proficiency level \\
& Reach education purposes \\
& Interest in languages \\
& Love learning Turkish \\
& Necessity in daily life \\
& Low recognition in international sphere \\
& Already achieved a satisfactory L2 level \\
& Proficiency level \\
\hline
\end{tabular}

Table 8 indicated that the learners would like to continue studying both languages in order to reach some educational goals and because of their pure interest in learning additional languages. Emphasizing the role of languages in education, a student said: "After my graduation, I will continue to study Turkish because I need it during my education in Turkey [and] I will continue to study English because I want to be a good speaker of English as it is necessary for better education." The international role of English in the global world is a distinct category for learning English. On this issue, a student said: "I would like to continue English. Because nowadays in the world all people speak English, and the better you speak English, the more you have credibility in the world." It should also be noted that some students only wanted to continue studying English rather than Turkish, due to the lower status of Turkish among world languages. For instance, one learner said: "[I do not want to study Turkish] because it is not accepted by many countries and I think that, even in Turkey, English is becoming more important in every level of studying system." Lastly, some learners said they would decide it later because they would like to see their actual level of proficiency after the completion of the courses.

\section{Discussion}

This study investigated the multilingual learners' motivational factors in learning additional languages: English and Turkish. The findings indicated that multilinguals' motivation types, L2 anxiety, and motivational strength to study English are moderately correlated with those of Turkish. None of the motivational factors, except L2 anxiety, differed when it comes to English or Turkish. The learners' beliefs regarding the variables presented some insights about why the 
learners learn, how they feel while learning and whether they would like to study the additional languages.

Descriptive statistics showed that multilingual students had the highest mean in extrinsic motivation among motivation types. They also had a relatively low level of anxiety in learning both languages and had the motivational strength to go on learning these languages. Correlation analyses showed that the learners had similar features concerning the learning of two additional languages; motivational construct in one language was significantly correlated with the same construct in another language though the correlations accounted small percentage of the variables. In other words, if a multilingual learner has the higher intrinsic motivation to learn a language, s/he might be intrinsically motivated to learn another language at some degree no matter these two languages can be different in terms of international recognition or linguistic structure. Though these are descriptive results, they partially correspond with findings reported by several researchers that multilingual learners are competent learners of other languages (Budría \& Swedberg, 2014; Cenoz, 2013; Cummins, 2009; Swain, 2000; Thompson \& Khawaja, 2016) and they feel little anxiety about learning additional languages (Dewaele et al., 2008; Santos et al., 2015; Thompson \& Lee, 2013) as there were weak correlations between the variables.

Comparison analyses showed that the multilingual learners showed similar characteristics in terms of intrinsic, extrinsic and integrative motivation, and motivational strength for learning languages and their scores were statistically similar for learning Turkish and English. It should be noted that unlike the hypothesis that the role of two distinct languages in the international job market and necessity in the international platform might play roles in L2 motivation, the participants were motivated by similar goals and expectations. Because König (2005) emphasized that language learners sometimes learn additional languages for pragmatic reasons; knowing a highly prestigious language such as English may reduce the student's motivation to learn a less prestigious language such as Turkish. Due to the increasing demand for English as an international language, even language learners in multilingual countries such as Switzerland and Belgium tend to learn English as their first foreign language, rather than one of the country's other national languages (Hoffmann, 2000). In terms of integrativeness in the study, it seemed that integrative motivation is still valid for both languages. This finding is inconsistent with the literature proposing that integrativeness does not play a significant role in learning L2 and might be more important in learning a globally less-known language than the international language, English, and is relevant to other L2 contexts (Chen, Warden, \& Chang, 2005; Lai, 2013; Lamb, 2004; SugitaMcEown, Noels, \& Saumure, 2014; Yashima, 2002, 2009; Yashima, Zenuk-Nishide, \& Shimizu, 2004). This issue might be related to misguidance of integrative items for the English language, and learners might associate the items with the international community, not particular an English community or culture, in other words, international posture (Yashima, 2009). Also concluded by Lai (2013), the idea 
of integrative motivation is dimming in an EFL context, Taiwan, where learners have very little opportunity to move or live in the target community and "the only community for EFL learners to integrate to is the international community” (p. 213).

However, their L2 anxiety within the learning environment statistically differentiated in favor of English. The anxiety in learning Turkish was significantly higher than English. This result might be related to the level of exposure to the additional languages (Dewaele, 2007; Dewaele et al., 2008). Turkish was a new and unfamiliar language to the students unlike English, and they had less exposure to Turkish before. They were also less proficient in communicating in Turkish. As Dewaele and colleagues (2008) reported, a high level of exposure to additional languages results in lower anxiety in learning and a higher level of self-perceived proficiency in a language are linked to lower levels of L2 anxiety.

Analysis of the qualitative responses enabled a comprehensive understanding of L2 motivational factors. In terms of motivation types, the students' responses showed some similarities in the two languages. It seemed that intrinsic reasons like learning languages because of the personal interest in other languages and cultures or the joy of learning additional languages were common for both languages. Also, extrinsic reasons such as gaining a better education and career, or creating good job opportunities are common reasons for the learners. Even though learning the languages to integrate into the culture showed some similarities, learning a language in a context where the native speakers speak the language and the learners use it as a way of communication in daily life seemed more influential especially in learning Turkish. As known that L2 motivation is strongly related to the context where you learn the language. As reported by Li (2014), Chinese ESL (English as a Second Language) differed than Chinese EFL learners in terms of L2 motivation types. Chinese learners of English in New Zealand ESL context were more motivated than the learners in China. In addition to these three common motivation types, two distinct thematic categories, 'learning English simply because it is an international language' and ' to travel across the world' have emerged in learning English. This finding is in line with other studies (e.g., Dörnyei, 1990; Ryan, 2006; Schmidt et al., 1996; Ushioda \& Dörnyei, 2012; Yashima, 2002), but further research is definitely needed in this area.

The learners' feelings about learning both languages showed similar characteristics when the learners felt relaxed while learning the languages. Positive beliefs such as personal interest or enjoying learning a new language are the common reasons. Being exposed to English much, and linguistic familiarity of Turkish made them relaxed while learning the additional languages. Several researchers (Konig, 2005; Sağın-Şimsek, 2014; Schüppert \& Gooskens, 2011) also confirmed that grammatically similar and closely related languages ease learning one another and boost positive attitudes towards learning additional languages. But when the learners were anxious in the learning process, there occurred some differences. At this point, the perception of the difficulty of Turkish and the newness of the language seemed important. In parallel to literature, prior learning 
experiences and familiarity with the language learning process between languages can reduce the level of anxiety in learning an additional language and can also assist in learning the subsequent language (Dewaele, 2007; Dewaele et al., 2008; Kemp, 2007; Konig 2005; Schüppert \& Gooskens, 2011; Thompson, 2013; Thompson \& Lee, 2013). Also, it is consistent with the assertion of Dewaele and Ip (2013) that studying languages other than English is related to L2 anxiety in other language and reduce the amount of L2 anxiety in English. Echoing the findings in the literature, language teachers' behaviors and teacher-related factors were influential on learners' feelings. For instance, irrelevant teaching approaches of teachers made a negative impact on students' perception towards the language learning process (Gorham \& Christophel, 1992; Sakai \& Kikuchi, 2009).

Last but not least, the learners reported that they would like to continue studying the languages after graduation since they considered Turkish and English as tools for reaching their educational goals, or as an important step for their future. In parallel with Lasagabaster's (2013) findings, it was also found that learner's perceptions of the target society, culture and society in the choice to go on studying the additional languages appeared to play a crucial role. It should also be noted that few learners did not agree with this view, and emphasized that the status of the language on the international stage played a significant role in their decisions (Hoffmann, 2000; House, 2003). Moreover, these students showed disinterest in learning Turkish, since Turkish is not a globally-accepted international language in the same way as English.

\section{Conclusions}

Overall, this study provided some useful insights into the motivational factors during learning simultaneous additional languages. The study supported some findings with the literature that the multilingual learners have personal interests in learning other languages and cultures; they have less anxiety and more desire to go on studying languages. It also highlighted that though there are no statistical differences in terms of motivation types in both languages, the frequencies and the reasons for qualitative results pointed to some potential differences in motivational factors and supported the literature. It showed that the integrativeness can be still valid for the learners of English and also the learners who would like to stay and live in the target languages' community or country. Learning a language inside or outside of the target language settings, high exposure to the target language, L2 teachers' teaching styles or characteristics, linguistics familiarity of target languages and the status of the target language in the world might be quite influential in learners' willingness to learn additional languages.

Although this study is significant with its multifaceted perspective of dealing with the simultaneous L2 learning situations and L2 motivation of the multilingual learners, it has two major limitations regarding the data collection and analysis process. First, this study has a cross-sectional data collection process and descriptive 
in nature. Considering that, longitudinal designs evaluating the factors in different periods are needed for presenting more causal relationships between the variables. Second, the relationship between demographic data of multilingual learners (e.g., the languages they know, fluency levels in languages or the length of study languages) and learning additional languages was disregarded in the study during the analysis. Therefore, motivational factors can be longitudinally investigated as further research, and the learners' background data can be considered to reach more concrete causal relationships. Moreover, to have a thorough understanding of the interfaces among the multilingualism, language learning motivation, and learning additional languages, additional research is needed to clarify the questions raised in the study. Furthermore, similar comparative studies with extended scopes can shed light on how motivational constructs take in multilingualism.

\section{Acknowledgments}

This study was presented orally at TESL Canada Conference 2017 and the author thanks to the reviewers for their insightful comments.

\section{References}

Balaman Uçar, S. (2009). The preferences of Turkish university EFL students for instructional activities in relation to their motivation. (Unpublished master's thesis). Bilkent University, Ankara.

BC \& TEPAV (2013). Turkey national needs assessment of state school English language teaching. Ankara: Yorum Press and Publishing. Retrieved from http://www.tepav.org.tr/upload/files/1399388356-5.Turkey_National_

Needs_Assessment_of_State_School_English_Language_Teaching.pdf

Boo, Z., Dörnyei, Z., \& Ryan, S. (2015). L2 motivation research 2005-2014: Understanding a publication surge and a changing landscape. System, 55, 145-157. Doi: 10.1016/j.system.2015.10.006

Budría, S., \& Swedberg, P. (2014). The Impact of multilingualism on Spanish language acquisition among immigrants in Spain, (IZA Dp No:8748). Retrieved from http://papers.ssrn.com/sol3/papers.cfm?abstract_id=2544812

Cenoz, J. (2013). Defining multilingualism. Annual Review of Applied Linguistics, 33, 3-18. Doi: 10.1017/S026719051300007X

Chen, J. F., Warden, C. A., \& Chang, H. T. (2005). Motivators that do not motivate: The case of Chinese EFL learners and the influence of culture on motivation. TESOL Quarterly, 39(4), 609-633. Doi: 10.2307/3588524

Creswell, J. W., \& Clark, V. L. P. (2007). Choosing a mixed methods design. In J. W. Creswell \& V. L. P. Clark (Eds.), Designing and conducting mixed methods research (pp. 58-88). Thousand Oaks, CA: Sage.

Csizér, K., \& Lukács, G. (2010). The comparative analysis of motivation, attitudes and selves: The case of English and German in Hungary. System, 38(1), 1-13. Doi: 10.1016/j.system.2009.12.001

Cummins, J. (2007). Rethinking monolingual instructional strategies in multilingual classrooms. Canadian Journal of Applied Linguistics, 10(2), 221-240, ERIC Number: EJ829536 
De Angelis, G. (2007). Third or additional language acquisition. Clevedon: Multilingual Matters.

Deci, E. L., \& Ryan, R. M. (1985). Intrinsic motivation and self-determination in human behavior. New York, NY: Plenum Press.

Dewaele, J. M. (2007). The effect of multilingualism, socio-biographical, and situational factors on communicative anxiety and foreign language anxiety of mature language learners. International Journal of Bilingualism, 11(4), 391-409. Doi: 10.1177/13670069070110040301

Dewaele, J. M., \& Ip, T. (2013). The link between foreign language classroom anxiety, second language tolerance of ambiguity and self-rated English proficiency among Chinese learners. Studies in Second Language Learning and Teaching, 3(1), 47-66.

Dewaele, J. M., Petrides, K. V., \& Furnham, A. (2008). The effects of trait emotional intelligence and sociobiographical variables on communicative anxiety and foreign language anxiety among adult multilinguals: A review and empirical investigation. Language Learning, 58(4), 911-960. Doi:10.1111/j.1467-9922.2008.00482.x

Dewaele, J. M., \& Wei, L. (2013). Is multilingualism linked to a higher tolerance of ambiguity?. Bilingualism: Language and Cognition, 16(1), 231-240. Doi: 10.1017/S1366728912000570

Dörnyei, Z. (1990). Conceptualizing motivation in foreign language learning. Language Learning, 4O(1), 45-78. Doi: 10.1111/j.1467-1770.1990.tb00954.x

Dörnyei, Z. (1998). Motivation in second and foreign language learning. Language Teaching, 31(3), 117-135. Doi: 10.1017/S026144480001315X

Dörnyei, Z. (2001). Motivational strategies in the language classroom. Cambridge: Cambridge University Press.

Dörnyei, Z. (2005). The psychology of the language learner: Individual differences in second language acquisition. Mahwah, NJ: Lawrence Erlbaum Associates.

Dörnyei, Z. (2009). The L2 motivational self system. In Z. Dörnyei \& E. Ushioda (Eds.), Motivation, language identity and the L2 self (pp. 9-42). Bristol, England: Multilingual Matters.

Dörnyei, Z., \& Al-Hoorie, A. H. (2017). The motivational foundation of learning languages other than Global English: Theoretical issues and research directions. The Modern Language Journal, 101(3), 455-468. Doi: 10.1111/modl.12408

Duff, P. A. (2017). Commentary: Motivation for learning languages other than English in an English-dominant world. The Modern Language Journal, 101(3), 597-607. Doi: 10.1111/modl.12416

Gardner, R. C. (1985). Social psychology and second language learning: The roles of attitudes and motivation. London: Edward Arnold.

Gorham, J. \& Christophel, D. M. (1992). Students' perceptions of teacher behaviors as motivating and demotivating factors in college classes. Communication Quarterly, 40(3), 239-252. Doi: 10.1080/01463379209369839

Hanson, W. E., Creswell, J. W., Plano Clark, V. L. Petska, K. S., \& Creswell, J. D. (2005). Mixed methods research designs in counseling psychology. Journal of Counseling Psychology, 52(2), 224-235.

Henry, A. (2010). Contexts of possibility in simultaneous language learning: Using the L2 Motivational Self System to assess the impact of global English. Journal of Multilingual and Multicultural Development, 31(2), 149-162. Doi: 10.1080/01434630903471439

Henry, A. (2011). Examining the impact of L2 English on L3 selves: A case study. International Journal of Multilingualism, 8(3), 235-255. Doi: 10.1080/01434630903471439 
Henry, A. (2017). L2 motivation and multilingual identities. The Modern Language Journal, 101(3), 548-565. Doi: 10.1111/modl.12412

Hoffmann, C. (2000). The spread of English and the growth of multilingualism with English in Europe. In J. Cenoz \& U. Jessner (Eds.), English in Europe: The acquisition of a third language (pp: 1-21). Clevedon: Multilingual Matters.

Horwitz, E. (2001). Language anxiety and achievement. Annual Review of Applied Linguistics, 21, 112-126. Doi: 0.1017/S0267190501000071

House, J. (2003). English as a lingua franca: A threat to multilingualism?. Journal of Sociolinguistics, 7(4), 556-578. Doi: 10.1111/j.1467-9841.2003.00242.x

Jaspaert, K., \& Lemmens, G. (1990). Linguistic evaluation of Dutch as a third language. In M. Byram \& J. Leman (Eds.), Bicultural and trilingual education: The Foyer model in Brussels (pp: 30-56). Clevedon: Multilingual Matters.

Jessner, U. (2008). Teaching third languages: Findings, trends and challenges. Language Teaching, 41(1), 15-56. Doi: 10.1017/S0261444807004739

Kemp, C. (2007). Strategic processing in grammar learning: Do multilinguals use more strategies?. International Journal of Multilingualism, 4(4), 241-261. Doi: 10.2167/ijm099.0

König, W. (2005). Language production in Turkish-German-English trilinguals. International Journal of Multilingualism, 2(2), 135-148. Doi: 10.1080/14790710508668381

Lai, H.T.Y. (2013). The motivation of learners of English as a foreign language. International Education Studies, 6(10), 90-101. Doi: 10.5539/ies.v6n10p90

Lamb, M. (2004). Integrative motivation in a globalizing world. System, 32(1), 3-19. Doi: 10.1016/system.2003.04.002

Lasagabaster, D. (2013). Attitudes and motivation in bilingual education. In C. A. Chapelle (Ed.), The encyclopedia of applied linguistics. Oxford: Wiley-Blackwell.

Lasagabaster, D., \& Doiz, A. (2015). A longitudinal study on the impact of CLIL on affective factors. Applied Linguistics, 38(5), 688-712. Doi: 10.1093/applin/amv059

Leung, C. (2016). English as an additional language -a genealogy of language-in-education policies and reflections on research trajectories. Language and Education, 30(2), 158-174. Doi: 10.1080/09500782.2015.1103260

Li, Q. (2014). Differences in the motivation of Chinese learners of English in a foreign and second language context. System, 42, 451-461. Doi: 10.1016/j.system.2014.01.011

Marshall, C., \& Rossman, G. B. (2016). Designing qualitative research (4 ${ }^{\text {th }}$ ed.). Los Angeles, CA: Sage Publications.

May, S. (2014). Introducing the "multilingual turn." In S. May (Ed.), The multilingual turn: Implications for SLA, TESOL and bilingual education (pp. 1-6). New York: Routledge.

Noels, K. A. (2001). Learning Spanish as a second language: Learners' orientations and perceptions of their teachers' communication style. Language Learning, 51(1), 107-144. Doi: 10.1111/0023-8333.00149

Noels, K. A. (2009). The internalisation of language learning into the self and social identity. In Z. Dörnyei \& E. Ushioda (Eds.), Motivation, language identity and the L2 self (pp. 295313). Bristol, UK: Multilingual Matters.

Noels, K. A., Pelletier, L. G., Clément, R., \& Vallerand, R. J. (2000). Why are you learning a second language? Motivational orientations and self-determination theory. Language learning, 50(1), 57-85. Doi: 0.1111/0023-8333.00111

Plonsky, L., \& Oswald, F. L. (2014). How big is "big"? Interpreting effect sizes in L2 research. Language Learning, 64(4), 878-912. Doi: 10.1111/lang.12079 
Ryan, S. (2006). Language learning motivation within the context of globalisation: An L2 self within an imagined global community. Critical Inquiry in Language Studies: An International Journal, 3(1), 23-45. Doi:10.1207/s15427595cils0301_2

Ryan, R. M., \& Deci, E. L. (2017). Self-determination: Basic psychological needs in motivation, development, and wellness. New York, NY: Guilford Press.

Sağın-Şimşek, Ç. (2014). Receptive multilingualism in Turkish-Turkmen academic counseling sessions. Applied Linguistics Review, 5(1), 195-210. Doi: 10.1515/applirev2014-0009

Sakai, H., \& Kikuchi, K. (2009). An analysis of demotivators in the EFL classroom. System, 37(1), 57-69. Doi: 10.1016/j.system.2008.09.00

Santos, A., Cenoz, J., \& Gorter, D. (2015). Communicative anxiety in English as a third language. International Journal of Bilingual Education and Bilingualism, 1-14. Doi: 10.1080/13670050.2015.1105780

Schmidt, R., Boraie, D., \& Kassabgy, O. (1996). Foreign language motivation: Internal structure and external connections. In R. Oxford (Ed.), Language learning motivation: Pathways to the new century (Technical Report \#11) (pp. 9-70). Honolulu: University of Hawaii, Second Language Teaching \& Curriculum Center.

Schmidt, R., \& Watanabe, Y. (2001). Motivation, strategy use, and pedagogical preferences in foreign language learning. In Z. Dörnyei and R. Schmidt (Eds.), Motivation and second language acquisition (pp. 313-359). Honolulu: University of Hawaii, Second Language Teaching \& Curriculum Center.

Schüppert, A., \& Gooskens, C. (2011). Investigating the role of language attitudes for perception abilities using reaction time. Dialectologia: Revista Electrònica, Special Issue II, $119-140$.

Skutnabb-Kangas, T., Maffi, L., \& Harmon, D. (2003). Sharing a world of difference: the earth's linguistic, cultural and biological diversity. UNESCO.

Sugita-McEown, M., Noels, K. A., \& Saumure, K. D. (2014). Students' self-determined and integrative orientations and teachers' motivational support in a Japanese as a foreign language context. System, 45, 227-241. Doi: 10.1016/j.system.2014.06.001

Swain, M. (2000). French immersion research in Canada: Recent contributions to SLA and applied linguistics. Annual Review of Applied Linguistics, 20(1), 199-212. Doi: 10.1017/S0267190500200123

Ortega, L. (2013). SLA for the 21st century: Disciplinary progress, transdisciplinary relevance, and the bi/multilingual turn. Language Learning, 63(1), 1-24. Doi: 10.1111/j.1467-9922.2012.00735.x

Thompson, A. (2009). The multilingual/bilingual dichotomy: An exploration of individual differences. (Unpublished doctoral dissertation). Michigan State University, USA.

Thompson, A. (2013). The interface of language aptitude and multilingualism: Reconsidering the bilingual/multilingual dichotomy. The Modern Language Journal, 97(3), 685-701. Doi: 10.1111/j.1540-4781.2013.12034.x

Thompson, A. S., \& Aslan, E. (2015). Multilingualism, perceived positive language interaction (PPLI), and learner beliefs: What do Turkish students believe?, International Journal of Multilingualism, 12(3), 259-275. Doi: 10.1080/14790718.2014.973413

Thompson, A. S., \& Erdil-Moody, Z. (2016). Operationalizing multilingualism: language learning motivation in Turkey. International Journal of Bilingual Education and Bilingualism, 19(3), 314-331. Doi: 10.1080/13670050.2014.985631

Thompson, A. S., \& Khawaja, A. J. (2016). Foreign language anxiety in Turkey: The role of multilingualism. Journal of Multilingual and Multicultural Development, 37(2), 115-130. Doi: 10.1080/01434632.2015.1031136 
Thompson, A. S., \& Lee, J. (2013). Anxiety and EFL: Does multilingualism matter?. International Journal of Bilingual Education and Bilingualism, 16(6), 730-749. Doi:10.1080/13670050.2012.713322

Thompson, A. S., \& Lee, J. (2016). The motivational factors questionnaire in the Korean EFL context: Predicting group membership according to English proficiency and multilingual status. The Language Learning Journal, 1-23. Doi:10.1080/09571736.2015.1130082

Ushioda, E. (2009). A person-in-context relational view of emergent motivation, self and identity. In Z. Dörnyei and E. Ushioda (Eds.), Motivation, language identity and the L2 self (pp. 215-228). Bristol: Multilingual Matters.

Ushioda, E., \& Dörnyei, Z. (2012). Motivation. In S. Gass, \& A. Mackey (Eds.), The Routledge handbook of second language acquisition (pp. 396-409). New York: Routledge.

Ushioda, E., \& Dörnyei, Z. (2017). Beyond global English: Motivation to learn languages in a multicultural world: Introduction to the special issue. The Modern Language Journal, 101(3), 451-454. Doi: 10.1111/modl.12409

van Compernolle, R. A. (2016). Are multilingualism, tolerance of ambiguity, and attitudes toward linguistic variation related? International Journal of Multilingualism, 13(1), 6173. Doi: 10.1080/14790718.2015.1071821

Varisoglu, B. (2018). Motivation to learn Turkish in foreign students with different thinking styles in terms of functional and formal aspects. Educational Research and Reviews, 13(9), 328-335.

Wei, L. (2008). Research perspectives on bilingualism and multilingualism. In Wei, L. \& M. Moyer (Eds.), The Blackwell guide of research methods in bilingualism and multilingualism (pp. 3-17). Oxford: Blackwell.

Yashima, T. (2002). Willingness to communicate in a second language: The Japanese EFL context. Modern Language Journal, 86(1), 54-66. Doi: 10.1111/1540-4781.00136

Yashima, T. (2009). International posture and the Ideal L2 self in the Japanese EFL context. In Z. Dörnyei, \& E. Ushioda (Eds.), Motivation, language identity and the L2 self (pp. 144163). Bristol: Multilingual Matters.

Yashima, T., Zenuk-Nishide, L., \& Shimizu, K. (2004). The influence of attitudes and affect on willingness to communicate and second language communication. Language Learning, 54(1), 119-152. Doi: 10.1111/j.1467-9922.2004.00250.x

\section{Appendix A.}

Intrinsic Motivation

1. I am studying this language because learning this language is very enjoyable.

2. I am studying this language because I enjoy using this language outside of class when I have the opportunity.

3. I am studying this language because learning this language makes me happy.

4. I am studying this language because learning this language is challenging but enjoyable.

5. I am studying this language even if it were not required because it is a hobby for me.

Extrinsic Motivation

1. I am studying this language to get a better job.

2. I am studying this language to understand the media in this language.

3. I am studying this language to improve my social status. 
4. I am studying this language to have financial benefits.

Integrative Motivation

1. I am studying this language because I want to be closer to the culture of this language.

2. I am studying this language because I want to live in a country speaking this language.

3. I am studying this language because I want to be able to interact with the speakers of this language.

4. I am studying this language because I want to have friends speaking this language.

\section{Anxiety}

1. I feel uneasy when I take an exam in this language.

2. I worry that other students will laugh at me when I speak this language.

3. I feel uncomfortable when I have to speak in this class.

4. It is embarrassing to volunteer answers in this class.

5. I feel more uncomfortable in this class than in other classes.

6. I think I can learn this language well, but I do not perform well on tests and examinations.

7. I do not want to speak often in this class because I do not want the teacher to think I am a bad student.

Motivational Strength

1. I will continue to study this language after I finish this class.

2. I will truly put my best effort into learning this language.

3. I intend to have very good attendance in this class.

4. I learn something new every day in this class.

5. I think this class is a good opportunity to learn this language.

6. I often think about how I can learn this language better.

\section{Copyrights}

Copyright for this article is retained by the author(s), with first publication rights granted to the Journal.

This is an open-access article distributed under the terms and conditions of the Creative Commons Attribution license (CC BY-NC-ND) (http://creativecommons.org/licenses/by-nc-nd/4.0/). 